\title{
Ankara, İstanbul ve İzmir Büyükşehir Belediyeleri'nin Twitter Kullanımına Yönelik Eğilimleri ve Takipçilerinin Tepkileri Üzerine Bir Analiz
}

\section{An Analysis of Ankara, Istanbul and Izmir Metropolitan Municipalities' Tendency to use Twitter and The Reactions of their Followers}

\author{
Dr. Öğr. Üyesi Yusuf Uysal ${ }^{1}$
}

Başvuru Tarihi: 14.05.2019

Kabul Tarihi: 13.09.2019

Öz

Bu çalışma iki bölümden oluşmaktadır. Birinci bölümde, sektörler ve sektör dışı faaliyetler temelinde Ankara, İstanbul ve İzmir Büyükşehir Belediyeleri'nin (BB)Twitter kullanım eğilimleri incelenmektedir. İkinci bölümde BB'lerin paylaşımlarına takipçilerin "beğeni", "retweet" ve "yorum" şeklindeki tepkileri karşılaştırmalı olarak analiz edilmektedir. Böylece, BB'lerin bir sosyal medya platformu olarak Twitter'i nasıl kullandıklarının tespit edilmesi ve takipçilerin paylaşımlara yönelik tepkilerinin ölçülmesi amaçlanmaktadır. BB'lerin çok çeşitli sektör ve alanlarda görev ve sorumluluklarının bulunması nedeniyle, paylaşımlar "sektör" veya "sektör dişı hizmet alanları" ile ilgili olanlar şeklinde gruplandırılmıştır. Bu bağlamda, 14 sektör gurubu ve 5 sektör dışı faaliyet alanı gurubu oluşturulmuş, değerlendirmeler ve analizler bu gruplandırma temelinde yapılmıştır. Bu analiz, inceleme konusu BB'lerin 01.10.2018 ile 31.12.2018 tarihleri arasındaki Twitter paylaşımlarını kapsamaktadır. Araştırmadaki veriler, Microsoft Excel Programı kullanılarak analiz edilmiştir.

Anahtar Kelimeler: Sosyal Medya, Twitter, Büyükşehir Belediyeleri, Yerel Yönetimler

\begin{abstract}
This study consists of two parts. In the first chapter, the tendency of use of Ankara, Istanbul and İmir Metropolitan Municipalities (MM) on the basis of sectors and non-sectoral activities are examined. In the second chapter, the reactions of the followers to the sharing of MMs shape of "likes", "retweets" and "comments" are analyzed comparatively. Thus, it is aimed to determine how the MMs use Twitter as a social media platform and to measure the reactions of the followers towards the shares. Due to the MMs have duties and responsibilities in a wide range of sectors and areas, the shares are grouped into "sector" or "non-sector service areas". In this context, 14 sector groups and 5 non-sectoral activities groups were formed, assessments and analyzes were made on the basis of this grouping. This analysis includes the Twitter shares of the MMs under review between 01.10.2018 and 31.12.2018. The data in the study were analyzed using the Microsoft Excel Program.
\end{abstract}

Keywords: Social Media, Twitter, Metropolitan Municipalities, Local Governments 


\section{Giriş}

21. Yüzyıl bilimsel ve teknolojik gelişmelere bağlı olarak haberleşme ve iletişim imkânlarının önceki çağlarla kıyaslanamayacak derecede yoğun olarak yaşandığı ve bu gelişmelerin hayatı kolaylaştırıcı etkilerinin en çok hissedildiği dönem olmasıyla "Dijital çağ" olarak da adlandırılmaktadır. Özellikle bu yüzyılın son çeyreğinde dijitalleşme sürecinin en önemli parametresi olarak internet teknolojileri siyasi, sosyal, kültürel ve ekonomik hayatın her aşamasında etkisini göstermiş, bireysel ve toplumsal yaşamın köklü değişim ve dönüşümüne sebep olmuştur. Bu gelişmeler kişisel ve toplumsal ölçekte üretim, tüketim, alışveriş, eğlence, yatırım, ulaşım ve iletişim gibi çok çeşitli alanlarda yeni yöntemlerin ortaya çıkmasına ve alışkanlıkların değişmesine veya yeni alışkanlıklar edinilmesine yol açmıştır.

Yaşamın her alanında köklü etkileri ve sonuçları görülen dijitalleşme sürecinin kamu hizmetleri üzerine de önemli etkileri olmuştur. Bu etkilerin en önemlilerinden biri sosyal medya kullanımının yaygınlaşması ile gerçekleşmiştir. Merkezi ve yerel yönetimler tarafından sunulan kamu hizmetlerinin ve faaliyetlerin doğrudan ve anlık olarak halka duyurulmasına ve halkın tepkilerinin doğrudan ve anlık olarak ölçülmesine imkân vermesi sosyal medya platformlarının kamu hizmet birimleri tarafından yoğun olarak kullanılmasına neden olmuştur. $\mathrm{Bu}$ özellikleriyle sosyal medya kamu politikalarının belirlenmesinde ve kamu hizmetlerinin sunulmasında vatandaşların katılımını ve işbirliğini arttıran bir rol oynamaktadır. Özellikle mahalli ve müşterek ihtiyaçların karşılanmasında esas yetki ve sorumluluk sahibi olan yerel yönetim birimleri için sosyal medyanın önemi gün geçtikçe artmaktadır.

Bu çalışma iki (2) bölümden oluşmaktadır. Birimci bölümde çalışmada kullanılan metodoloji ve sosyal medyanın kavramsal boyutu ele alınmakta; ikinci bölümde çalışmanın bulgularına yer verilmektedir. İkinci bölümde ilk olarak, Ankara, İstanbul ve İzmir BB’lerinin Twitter kullanımlarıyla ilgili genel bilgiler ve BB'lerin Twitter'da paylaşım eğilimleri incelenmektedir. Daha sonra BB'lerin paylaşımlarına takipçilerin verdikleri tepkiler ele alınmaktadır. Hem Twitter paylaşımları hem de "beğeni” "retweet" ve "yorum” şeklindeki takipçi tepkileri sektörler ve sektör dışı faaliyet alanlarına göre ayrılmakta ve karşılıklı olarak analiz edilmektedir.

\section{Metodoloji}

$\mathrm{Bu}$ araştırmada, öncelikle Ankara, İstanbul ve İzmir BB'lerinin resmi Twitter hesaplarından 01.10.2018 ile 31.12.2018 tarihleri arasında yapılan paylaşımlar (tweetler) sektörlere veya sektör dışı hizmet alanlarına göre listelenmiştir. BB’lerin görev ve sorumluluklarının genişliği nedeniyle sektörler ve faaliyet alanlarının gruplandırılması yoluna gidilmiştir. Bu kapsamda, paylaşımlar 14 sektör grubu ve 5 sektör dışı faaliyet alanı grubu olmak üzere toplam 19 kategoride toplanmıştır. Kategorilere ayrılan paylaşımlar Microsoft Excel Programı yardımıyla analiz edilmiştir.

\section{Sosyal Medya: Kavramsal Çerçeve}

World Wide Web'in ilk versiyonu olan ve 1989'dan 2005'e kadar uygulanan Web 1.0 "bilgi bağlantısı ağı” olarak tanımlanmıştır. Kullanıcıların pasif durumda olduğu Web 1.0, kullanıcılar ile bilgi alışverişi ve etkileşim sağlamada oldukça düşük olanaklara sahipti (Khanzode ve Sarode, 2016, s. 2). İlk bakışta farklı bir dünyaya aitmiş gibi görünen World Wide Web'in bu versiyonu düşük düzeyde etkileşim, nispeten az sayıda bilgi üreticisi ve bir kaynaktan çoklu alıcılara doğru 
iletişim şekli ile karakterize edilmektedir. Bu versiyonda bireyler, genellikle aralıklı olarak eposta, Usenet ve ilanlara erişimler yoluyla içerik oluşturmuşlardır (Ellison ve Hardey, 2014, s. $24)$.

Web 2.0 versiyonu ise, daha önce pasif olan web kullanıcılarının aktif içerik oluşturmalarına izin vermesiyle interneti dönüştürmüştür (Dadashzadeh, 2010, s. 81). Bu versiyonun geniş çapta tanınmasına sebep olan olayların başında kullanıcıların her zaman bağlanabilmelerini sağlayan mobil cihazların yaygınlaşması gelmektedir. Günümüzde kullanıcılar, çok çeşitli platformlarda metinlerin yanı sıra resim ve video gibi içerikleri tek başlarına veya birlikte sorunsuz bir şekilde oluşturabilmekte ve en önemlisi paylaşabilmektedir (Ellison ve Hardey, 2014, s. 24). Web 2.0'in sahip olduğu en önemli yenilik yöneticilere ve vatandaşlara internet üzerinden paylaşılan veri ve bilgileri işbirliği içinde oluşturmak için platformlar sunmasıdır (Seigler, 2017, s. 74).

Web'in versiyonlarındaki bu değişimler bilgi ve iletişim teknolojilerinin huzla gelişmesine örnek oluşturmaktadır. Bilgi ve iletişim teknolojilerindeki bu gelişmeler, bireysel ve sosyal hayatı önemli ölçüde etkilerken hem özel sektör hem kamu sektörünün iş, işlem ve faaliyetlerinde değişim ve dönüşüm yaşanmasına sebep olmuştur. Hükümetler vatandaşların daha fazla bilgiye erişimini, kurumsal şeffaflığı, katılımcı karar vermeyi sağlamak ve kamu hizmetlerine erişimin arttırılmasını gerçekleştirmek amacıyla bilgi ve iletişim teknolojileri ve interneti kullanmaya başlamışlardır (Tursunbayeva vd., 2017, s. 270). Kamu hizmetlerinde bilgi ve iletişim teknolojilerinin kullanılmasıyla "e-devlet" kavramı ortaya çıkmış ve zamanla içeriği genişlemiştir.

E-devlet, bilgi ve iletişim teknolojilerinin daha iyi bir hükümet için kullanılması veya özellikle internet ve web teknolojilerinin kullanılmasıly hizmetlerin kalitesinin artırılması olarak tanımlanmaktadır (Oecd, 2003, s. 1). Teknik, örgütsel ve yönetsel fizibilite ve bunlara ilişkin örnekler e-devletin sürekli bir gelişme sürecine sahip olduğunu ortaya koymaktadır. Bu bağlamda, e-devlet için büyüme modeli "kataloglama", "işlem", "dikey bütünleşme" ve "yatay bütünleşme" olmak üzere dört aşamada ortaya çıkmaktadır. Farklı entegrasyon seviyeleri ile açıklanan bu dört aşamanın birincisi olan "kataloglama" aşaması, kamu kurumlarının web sitesi oluşturma yolu ile tek taraflı bilgi sunmasını ifade ederken; "işlem" aşaması, web siteleri yolu ile çift taraflı iletişimin gerçekleştirilmesini ifade etmektedir. Kamu yönetiminde işlevsel faaliyetlerin bütünleşmesi üçüncü aşama olan "yatay bütünleşme" aşamasında gerçekleştirilmektedir. Kamu yönetiminde farklı faaliyet alanlarındaki kurumların kullanıcılara tek bir elektronik hizmet merkezinden bilgi ve hizmet sunabilmeleri ise, "dikey bütünleşme" aşaması olarak adlandırılmaktadır. "Kataloglama" ve "işlem" aşamalarında kamusal bilgi ve işlem için bir elektronik ara yüzey oluşturmak öncelikli hedef olmasına rağmen, "yatay bütünleşme" ve "dikey bütünleşme" aşamalarında var olan devlet yapısında sunulan e-devlet hizmetlerinin bütünleştirilmesine odaklanılmaktadır (Layne ve Lee, 2001, s. 123-124).

E-devlet hizmetlerini tamamlayıcı bir araç olarak sosyal medyanın rolü artı̧ gösterme eğilimindedir. İnsanların sanal topluluklardaki diğer insanlarla çoklu ortam bilgilerini oluşturmalarını, paylaşmalarını, etkileşim kurmalarını, işbirliği yapmalarını ve paylaşmalarını sağlayan çevrimiçi bir iletişim aracı olarak tanımlanabilen sosyal medya (Nepal, vd., 2015, s. 34); belirtilen fonksiyonları kamu hizmetleri ve kamu kurumları için de gerçekleştirmektedir. Sosyal medya kamu hizmetleri ile ilgi oluşturulan içeriklerin akıllı telefonlar ve tablet 
bilgisayarlar gibi mobil teknolojilerle hızlı bir şekilde yayınlanmasına ve dağtılımasına olanak sağlamaktadır (Ellison ve Hardey, 2014, s. 24 ).

Mobil ve web tabanlı teknoloji kullanımlarındaki artışla birlikte yaygınlaşan sosyal medya, bireylerin ve toplulukların kullanıcı tarafindan oluşturulan içeriği paylaşma, birlikte oluşturma, tartışma ve değiştirme yoluyla yüksek düzeyde etkileşimli platformlar oluşturmaktadır (Kietzmann vd., 2011, s. 241). Bu bağlamda, sosyal medya sosyal etkileşimi kolaylaştıran, işbirliğini mümkün kılan ve paydaşlar arasında müzakere sağlayan teknolojilerdir. $\mathrm{Bu}$ teknolojiler arasında bloglar, wiki'ler, medya (ses, fotoğraf, video, metin) paylaşım araçları, ağ platformları ve sanal dünyalar bulunmaktadır. Özel sektör şirketleri daha çok müşteriye ulaşmak ve satışlarını arttırmak için sosyal medyaya yatırım yapmanın önemini anlamış ve hızla sosyal medyadaki yatırımlara odaklanmışlardır (Dadashzadeh, 2010, s. 81). Kamu yönetiminde ise, yöneticiler ve teorisyenler devletin şeffaflığını, halkın katılımını, hükümetler ve sektörler arası işbirliğini arttırmak için sosyal medya ve ağ oluşturma araçlarının dönüştürücü etkisini sıklıkla vurgulamaktadırlar (Bryer ve Zavattaro, 2011, s. 325-327).

Kamu ve özel tüm kullanıclar için "işbirliğì", "katılım", "güçlendirme" ve "zaman" olarak dört ana potansiyel güce sahip olan sosyal medya, "sosyal etkileşim" şeklinde tanımlandığı gibi doğası gereği işbirlikçi ve katılımcı bir yapıya sahiptir. Sosyal medya kullanıcıların birbirleriyle bağlantı kurmaları suretiyle sosyalleşmeleri, bilgi paylaşımı yapmaları veya ortak bir hedef belirlemeleri için topluluklar oluşturmaya olanak sağlamaktadır. Ayrıca, sosyal medya kullanıcılarına konuşma platformu oluşturma imkanı verdiği için onları güçlendirici bir etkiye de sahiptir. Sosyal medya vasıtasıly internete erişimi olan herkesin medyayı demokratikleştirme ve bilgiyi anında, gerçek zamanlı ve ucuz bir şekilde yayma olanağını vardır (Magro, 2012, s. 149).

Seigler'e göre, sosyal medyanın kamu yöneticileri tarafından benimsenmesi ve sürekli hale dönüşmesi dört aşamadan meydana gelmektedir. Bu aşamalardan birincisi sosyal medya kullanımının henüz hiç olmadığı aşamadır. Daha sonra sırasıyla "ortaya çıkan sosyal medya kullanımı", "ileri sosyal medya kullanımı" ve "işbirliğine dayalı sosyal medya kullanımı" aşamaları gelmektedir. "İşbirliğine dayalı sosyal medya kullanımı" aşaması sosyal medya kullanımının en yoğun olduğu aşama olup, bu aşamada vatandaşlar kamu yöneticileri tarafından politikalar, konular, hizmetler, hükümet planları, hizmet tasarımı ve yeni fikirler hakkında geri bildirimde bulunmaları konusunda teşvik edilmektedir (Seigler, 2017, s. 76 ).

Yerel yönetimlerde bir sosyal medya politikası tasarlamayı gerektiren kaynaklar, yasal konular, gizlilik, güvenlik, itibar yönetimi, yönetişim ve bilgi ve içerik konularında bir takım sorunlar yaşanmakla birlikte, sosyal medya halka yerel hizmetlerle ilgili mesajları göndermek ve karşllığında vatandaşlardan geri bildirim toplamak için kullanılmakla çeşitli firsatlar oluşturmaktadır (Karkin vd. 2015, s. 98). Sosyal medya, yerel yönetimlerin önemli bilgileri halka iletmeleri, devlet hizmetlerini genişletmeleri ve vatandaşlara yapılan kamu hizmetleri hakkında geri bildirim ve fikir almalarını sağlamaktadır. Sosyal medyanın açık diyalog niteliği, vatandaşlarla iletişimindeki hükümetlerin tecrübesiz kalmasına neden olan engellerin birçoğunun ortadan kalkmasına ve seçmenlerle iletişimin daha sık, açık ve hedeflenebilir olmasına imkân vermektedir (Graham vd., 2015, s. 386). 
Ayrıca, sosyal medya halkla iletişim kurmak ve yerel yönetim işlemlerini kolaylaştırmak için oldukça yararlı ve güçlü bir araç olma potansiyeli taşımaktadır. Bir web sitesinin ötesine geçen sosyal medya, bilgileri hızla paylaşmak için oldukça yararlı bir işlev görmektedir. Sosyal medyanın potansiyelini ve risklerini anlamak ve vatandaşların sosyal medyayı akıllıca kullanmalarına yardımcı olmak yerel yönetimlerin geliştirilmesine yardımcı olan faaliyetlerdir. Sosyal medya bir okuldaki gecikme veya okulun kapanışı, programlanmamış bir erken tahliye, olağandışı bir trafik durumu, önemli bir hava durumu olayı hakkında acil durum bilgisi, bir kamu güvenliği sorunu, bir toplantı iptali, yakında yapılacak bir duruşma, bir seçim için oy kullanma saatleri gibi çok çeşitli alanlarda ve önemli olaylar hakkında hızlı hatırlatmalar için oldukça faydalı avantajlar sağlamaktadır. Ayrıca, sosyal medya takipçilere sürekli bir "konuşma" seçeneği sunması ile halkı çeşitli konular hakkında uyarmanın bir yolu olabilmektedir (Filmore, 2012, s. 17-23).

Sosyal medyanın bunlar gibi faydaları yerel yönetimlerin ve hükümetlerin kriz zamanlarında vatandaşlarla iletişim kurmaları için özel fırsatlar sunmaktadır. Kriz zamanlarında sosyal medya, hükümetlerin ve diğer kuruluşların kitlelere ulaşmak için hızlı ve etkili bir şekilde iletişim kurmalarını sağlamaktadır. Özellikle konuşma ve etkileşim yoluyla açık bilgi alışverişi sağlayan bir araç olması nedeniyle sosyal medya afet müdahalesi için önemli bir teknoloji olarak kullanılmaktadır. Örneğin, Boston Şehrinde 2013 ylının başlarında Boston maraton bombalamaları sonrasında halkla iletişim kurmak için yoğun olarak sosyal medyadan yararlanmıştır. Vatandaşlara ve diğer ilgili taraflara yönelik krizler ve güvenlik protokolleri hakkında bilgi almak için Yosemite Ulusal Parkı'ndaki yangınlarda ve Colorado'daki tarihi sel sırasında hükümetin sosyal medya kullanımı da hayati öneme sahip olmuştur (Graham vd., 2015, s. 386 ).

Tüm bu avantajlarına rağmen, Kavanaugh'a göre, yerel yönetimler sosyal medya kullanımında yüksek bir bilinç ve farkındalık seviyesine sahip değildirler. Buna göre, yerel yönetim birimleri sosyal medyada takipçilerinin kim olduğu, örgütlerinde iletişimi kimin izlemesi gerektiği, takipçilere nasıl ve ne zaman cevap vermeleri gerektiği ve sosyal medya iletişiminin halk üzerinde ne gibi etkileri olduğu gibi konularda sosyal medyanın maliyet ve faydalarını bilmeden kullanmaktadırlar (Kavanaugh vd., 2012, s. 485). Küçük yerel yönetimlerde ise, sosyal medya kullanımı hakkında oldukça sınırlı bilgi söz konusudur (Gao ve Lee, 2017, s. 627).

Bilindiği üzere, dünya üzerinde oldukça yaygın olarak kullanılan çeşitli sosyal medya platformları kullanıcılarına çeşitli imkanlar sağlamaktadır. Mianka tarafından yapılan bir araştırmaya göre, kamu kurumları arasında en çok tercih edilen ve en fazla mesaj paylaşılan sosyal medya platformu Twitter'dır. Takipçileri ve beğeniler bakımından Facebook ve Twitter'ın Youtube'ye göre daha büyük önemi vardır. YouTube, bir çok hükümet tarafından kullanılmakla birlikte daha az abone sayısına sahip olmakla dikkat çekmektedir (Mainka vd., 2014, s. 1718).

\section{Bulgular}

Araştırmada elde edilen bulgular iki ana başlıkta incelenmektedir. Birinci başlıkta Ankara, İstanbul ve İzmir BB’lerinin Twitter paylaşım eğilimleri sektörlere ve sektör dışı faaliyet alanlarına göre analiz edilmektedir. İkinci başlıkta ise, bu paylaşımlara karşı takipçilerin 
“beğeni”, "retweet” ve “yorum” şeklindeki tepkisel davranış eğilimleri karşılaştırmalı olarak incelenmektedir.

\section{BB'lerin Paylaşım Eğilimleri île ilgili Bulgular}

Tablo 1'de görüldüğü üzere, Ankara, İstanbul ve İzmir BB'leri arasında Twitter platformunda ilk resmi hesap 17.01.2011 tarihinde üyelik kaydı yapan İstanbul BB tarafından açılmıştır. İstanbul BB'den yaklaşık bir yıl sonra Ankara BB ve bir buçuk yıl sonra da İzmir BB resmi hesap açmıştır. İlk hesap açan İstanbul BB olmakla birlikte takipçi sayısının il nüfusuna oranı itibariyle Ankara BB’nin diğer belediyelere önemli bir üstünlüğü söz konusudur. İstanbul il nüfusu Ankara nüfusundan yaklaşık üç kat fazla olmasına rağmen, Ankara BB'nin Twitter takipçi sayısı İstanbul BB'den yaklaşık \%63 daha fazladır. Ankara BB'nin takipçi sayısı İzmir BB’nin takipçi sayısının üç (3) katından daha fazla bir orana sahiptir. İller kendi içinde değerlendirildiğinde ise, İstanbul BB’nin takipçi sayısı İstanbul nüfusunun sadece \%2,30’u oranındadır. Bu oran İzmir'de \%4,16 Ankara'da ise, \%10.03'tür.

Bir BB’nin Twitter takipçilerinin daha çok o ilde yaşayan insanlardan oluştuğu varsayılırsa Ankara'lıların Ankara BB'yi takip etme konusunda daha istekli oldukları anlaşılmaktadır. Bu konuda en düşük orana \%2,30 ile İstanbul BB sahiptir. Tablo1'de BB'lerin “takip edilen Twitter hesabı", "toplam paylaşım sayısı" ve "BB’ler tarafından beğenilen hesap sayısı" itibariyle İstanbul BB’nin önemli oranda yüksek değerlere sahip olduğu görülmektedir. Özellikle, Twitter'da resmi hesap açma tarihleri arasında çok uzun zaman olmamasına rağmen İstanbul BB'nin İzmir BB'den yaklaşı 5 kat, Ankara BB'den 20 kat daha fazla paylaşım yapması İstanbul BB tarafından Twitter’ın daha aktif şekilde kullanıldığını ortaya koymaktadır.

Tablo 1. BB'lerin Twitter Üyelikleriyle İlgili Genel Bilgiler

\begin{tabular}{|l|c|c|c|c|c|c|c}
\hline & $\begin{array}{c}\text { Twitter'a } \\
\text { Üyelik } \\
\text { Tarihi }\end{array}$ & İl Nüfusu* & $\begin{array}{c}\text { Takipçi } \\
\text { Sayıs1 }\end{array}$ & $\begin{array}{c}\text { Takipçi } \\
\text { Sayısının } \\
\text { İl Nüfusuna } \\
\text { Oranı (\%) }\end{array}$ & $\begin{array}{c}\text { Takip } \\
\text { Edilen } \\
\text { Hesap } \\
\text { Sayıs1 }\end{array}$ & $\begin{array}{c}\text { Toplam } \\
\text { Paylaşım } \\
\text { Sayıs1 }\end{array}$ & $\begin{array}{c}\text { BB'ler } \\
\text { Tarafında } \\
\text { Beğeniler } \\
\text { Hesaplar }\end{array}$ \\
\hline Ankara BB & 12.12 .2011 & 5.503 .985 & 552.294 & 10,03 & 4 & 1.616 & 24 \\
\hline İstanbul BB & 17.01 .2011 & 15.067 .724 & 346.060 & 2,30 & 183 & 33.790 & 926 \\
\hline İzmir BB & 18.07 .2012 & 4.320 .519 & 179.608 & 4,16 & 71 & 7.031 & 507 \\
\hline
\end{tabular}

*TÜIK: http://www.tuik.gov.tr/UstMenu.do?metod=temelist. (19.02.2019) Not: Tablo, 19.02.2019 tarihindeki değerlere göre oluşturulmuştur.

Tablo 2'de araştırmanın kapsamına giren 01.10.2018 ile 31.12.2018 tarihleri arasındaki 91 günde BB'lerin paylaşım sayıları görülmektedir. Buna göre, İstanbul BB hesabından Ankara BB ve İzmir BB’ye göre önemli oranda daha fazla paylaşım yapılmıştır. Söz konusu 91 günlük dönemde Ankara BB hesabından günlük ortalama 2,35 paylaşım yapılırken, İzmir BB hesabından 3,09 paylaşım ve İstanbul BB hesabından 5,37 paylaşım yapılmıştır. Bu dönemde günlük paylaşım sayıları itibariyle İstanbul BB Ankara BB’nin iki (2) katından fazla paylaşım sayısına ulaşırken İzmir BB’nin ise, iki (2) katına yakın bir paylaşım gerçekleşmiştir. 
Tablo 2. Günlük Ortalama Paylaşım Sayıları

\begin{tabular}{|l|c|c|c|c|c}
\hline & Başlangıç Tarihi & Bitiş Tarihi & Gün Sayısı & Paylaşım Sayısı & $\begin{array}{c}\text { Günlük Ortalam } \\
\text { Paylaşım Sayıs1 }\end{array}$ \\
\hline Ankara BB & 01.10 .2018 & 31.12 .2018 & 91 & 214 & 2,35 \\
\hline İstanbul BB & 01.10 .2018 & 31.12 .2018 & 91 & 489 & 5,37 \\
\hline İzmir BB & 01.10 .2018 & 31.12 .2018 & 91 & 281 & 3,09 \\
\hline
\end{tabular}

Tablo 3'de araştırma kapsamındaki BB'lerin sektörlere ve sektör dışı faaliyet alanlarına göre Twitter'da paylaşım sayıları görülmektedir. Buna göre, Ankara BB’nin paylaşımlarının \%71,50'si herhangi bir sektörle ilgiliyken bu oran İstanbul BB'de \%74,85, İzmir BB'de ise, \%69,04 olarak gerçekleşmiştir. Ankara BB'nin herhangi bir sektörle ilgili olmayan faaliyet alanlarıyla ilgili paylaşım oranı \%28,50 olarak gerçekleşirken bu oran İstanbul BB'de \%25,15, İzmir BB'de ise, \%30,96 olarak gerçekleşmiştir. Bu değerlerden Ankara ve İzmir BB'lerine göre İstanbul BB'nin herhangi bir sektörle ilgili paylaşım oranlarının daha yüksek olduğu anlaşılmaktadır.

Ankara BB tarafından en çok paylaşım yapılan sektör toplam paylaşımların \%14,02'sini ( $\mathrm{n}=30$ ) oluşturan "diğer sektörler (tarım, turizm, il tanıtımı, sokak hayvanları, gıda, enerji)" olmuştur. Ankara BB’nin paylaşımlarında bu sektörlerin daha büyük bir orana sahip olmasında Ankara’nın tanıtımına yönelik paylaşımlar ile gıda alanında yapılan paylaşımların önemli etkisi olmuştur. Ankara BB tarafından yapılan toplam paylaşımların \%10,28’inin de (n=22) "metroloji ve iklim" sektörleriyle ilgili olduğu görülmektedir. Meteoroloji ve iklim sektörleriyle ilgili Ankara BB'nin paylaşımları genellikle olumsuz hava koşulları ile kar ve buzlanmalara karşı mücadele paylaşımlarından oluşmaktadır. Bu sektörlerde İstanbul BB’nin paylaşım oranının $\% 1,84(n=9)$, İzmir BB'nin paylaşım oranının \%0,36 $(n=1)$ oranında gerçekleşmiş olması bu alanda Ankara BB'nin diğer BB'lere oranla daha fazla iklim ve olumsuz hava koşullarıyla mücadele etmek zorunda kalması ile açıklanabilecek bir durumdur. 
Tablo 3. Paylaşımların Sektörlere ve Sektör Dıșı Faaliyetlere Göre Dağılım Oranları (\%)

\begin{tabular}{|c|c|c|c|c|c|c|c|}
\hline & \multicolumn{2}{|c|}{ Ankara BB } & \multicolumn{2}{|c|}{ İstanbul BB } & \multicolumn{2}{|c|}{ İzmir BB } \\
\hline & & 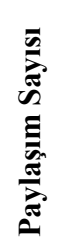 & 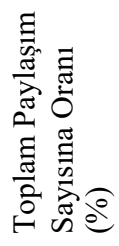 & 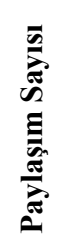 & 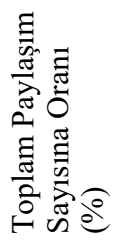 & 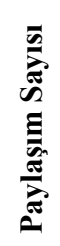 & 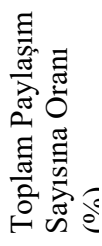 \\
\hline \multirow{14}{*}{ 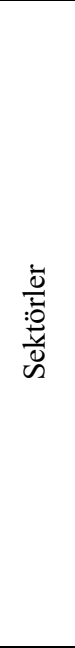 } & Atık, Arıtma, Geri Dönüşüm ve Temizlik & 3 & 1,40 & 24 & 4,91 & 2 & 0,71 \\
\hline & Bilim, Kültür ve Sanat & 3 & 1,40 & 24 & 4,91 & 30 & 10,68 \\
\hline & Bilişim ve Teknoloji & 9 & 4,21 & 20 & 4,09 & 1 & 0,36 \\
\hline & Eğitim ve Meslek Edindirme & 8 & 3,74 & 20 & 4,09 & 6 & 2,14 \\
\hline & Kentsel Planlama ve Dönüşüm & 6 & 2,80 & 8 & 1,64 & 8 & 2,85 \\
\hline & Medya ve Haber & 6 & 2,80 & 3 & 0,61 & 5 & 1,78 \\
\hline & Meteoroloji ve İklim & 22 & 10,28 & 9 & 1,84 & 1 & 0,36 \\
\hline & Park, Yeşil Alan ve Çevre & 7 & 3,27 & 46 & 9,41 & 22 & 7,83 \\
\hline & Sosyal Yardımlar ve Hizmetler & 11 & 5,14 & 17 & 3,48 & 13 & 4,63 \\
\hline & Spor ve Sağlık & 5 & 2,34 & 73 & 14,93 & 18 & 6,41 \\
\hline & Su, Kanalizasyon ve Altyap1 & 5 & 2,34 & 14 & 2,86 & 5 & 1,78 \\
\hline & Ulaşım, Trafik ve Toplu Taşıma & 21 & 9,81 & 68 & 13,91 & 30 & 10,68 \\
\hline & Genel (Birden Çok Sektör) & 17 & 7,94 & 17 & 3,48 & 26 & 9,25 \\
\hline & Diğer Sektörler* & 30 & 14,02 & 23 & 4,70 & 27 & 9,61 \\
\hline \multicolumn{2}{|r|}{ Sektörler Toplamı } & 153 & 71,50 & 366 & 74,85 & 194 & 69,04 \\
\hline \multirow{5}{*}{ 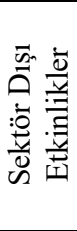 } & Belediye Organları ve Personel Faaliyetleri & 7 & 3,27 & 14 & 2,86 & 5 & 1,78 \\
\hline & Özel Gün, Anma, Kutlama, Dilek ve Tem. & 26 & 12,15 & 41 & 8,38 & 36 & 12,81 \\
\hline & Fuar, Panayır, Sergi, Şenlik vb. Etkinlikler & 3 & 1,40 & 6 & 1,23 & 22 & 7,83 \\
\hline & Sosyal Faaliyetler $* *$ ve Ziyaretler & 22 & 10,28 & 36 & 7,36 & 18 & 6,41 \\
\hline & Diğer*** & 3 & 1,40 & 26 & 5,32 & 6 & 2,14 \\
\hline \multicolumn{2}{|r|}{ Sektör Dışı Toplamı } & 61 & 28,50 & 123 & 25,15 & 87 & 30,96 \\
\hline \multicolumn{2}{|r|}{ Genel Toplam } & 214 & 100,00 & 489 & 100,00 & 281 & 100,00 \\
\hline
\end{tabular}

*(Tarım, Turizm (İl Tanıtımı), Sokak Hayvanları, Gıda, Enerji)

**(Cenaze, Nikah, Düğün vb.)

***(Denetimler, Cezalar, Doğal ve Tabi Afetler ve Diğer Etkinlikler)

Ankara BB tarafından en çok paylaşımın yapılan üçüncü sektör, toplam paylaşımların \%9,81'ini ( $n=21)$ oluşturan “ulaşım, trafik ve toplu taşıma” sektörleridir. Bu sektörler İstanbul BB'nin toplam paylaşımlarında $\% 13,91(n=68)$ oranıyla en çok paylaşım yapılan ikinci sektör olurken, İzmir BB'nin toplam paylaşımlarında \%10,68 $(\mathrm{n}=30)$ oranıyla en çok paylaşım yapılan sektör olmuştur. Bu sektörlerdeki paylaşımlar genellikle yol ve kavşak yapımı, toplu taşıma hizmetleri ve trafik sonunu çözme odaklı paylaşımlardır. "Ulaşım, trafik ve toplu taşıma" sektörünün İzmir BB'de en çok paylaşım yapılan sektör, İstanbul BB'de en çok paylaşım yapılan ikinci sektör ve Ankara BB'de de en çok paylaşım yapılan üçüncü sektör olması bu sektörün BB’lerin faaliyet alanlarındaki oranı ve sorunlara çözüm bulma çabalarının yoğunluğu konusunda fikir vermektedir.

İstanbul BB’nin paylaşımlarında "spor ve sağlık" sektörleri \%14,93 (n=73) oranla en çok paylaşım yapılan sektörler olmuştur. Bu sektörlerin yüksek paylaşım oranlarına sahip olmasında İstanbul BB spor kulüplerinin faaliyet ve müsabakalarıyla ilgili paylaşımlar büyük rol oynamıştır. İstanbul BB’nin paylaşımlarında “Spor ve sağlık” sektörlerini \%13,91 (n=68) oranla 
"ulaşım, trafik ve toplu taşıma" sektörleri ve \%9,41 (n=46) oranla "park, yeşil alan ve çevre" sektörleri takip etmektedir.

İzmir BB'nin paylaşımlarında ise, \%10,68 $(\mathrm{n}=30)$ oranla "ulaşım, trafik ve toplu taşıma" ile "bilim, kültür ve sanat" sektörleri ilk sırada yer almaktadır. Bu sektörleri \%9,61 ( $\mathrm{n}=27)$ oranla "diğer sektörler (tarım, turizm, il tanıtımı, sokak hayvanları, gıda, enerji)" sektörleri ve \%9,25 $(\mathrm{n}=26)$ oranla "genel (birden çok sektör)" takip etmektedir. İzmir BB'nin paylaşımlarında "bilim, kültür ve sanat" sektörlerinin yüksek oranlara sahip olmasında kültür ve sanat faaliyetleriyle ilgili paylaşımların rol oynamıştır.

Sektör dişı faaliyetlerde her üç BB’de de “özel günler, anma kutlama, dilek ve temenniler” en çok paylaşım yapılan faaliyet alanları olmuştur. Ankara ve İstanbul BB'de "sosyal faaliyetler ve ziyaretler" faaliyet alanları en çok paylaşım yapılan ikinci faaliyet alanı olurken, İzmir BB'de ise, en çok paylaşım yapılan ikinci faaliyet alanı "fuar, panayır, sergi, şenlik vb. etkinlikler" faaliyet alanları olmuştur. "Fuar, Panayır, sergi, şenlik vb. etkinlikler" faaliyet alanları Ankara ve İstanbul BB'lerinde en az paylaşım yapılan sektör dışı alanlar olmasına rağmen İzmir BB'de ikinci en çok çok paylaşım yapılan sektör dışı faaliyet alanı olması dikkat çekicidir. Sektör dışı paylaşımlarda diğer dikkat çeken bir nokta "diğer (denetimler, cezalar, doğal ve tabi afetler ve diğer etkinlikler” faaliyetleri ile ilgili Ankara BB’nin paylaşımları \%1,40 (n=3) ve İzmir BB'nin \%2,14 ( $\mathrm{n}=6)$ gibi oldukça düşük oranlarda gerçekleşmesine rağmen İstanbul BB’nin bu alanda yaptığı paylaşımların \%5,32 (n=26) olarak gerçekleşmesidir. Ayrıca "sosyal etkilinler ve ziyaretler” faaliyet alanlarında Ankara BB'nin ve belediye organları ve personel faaliyetlerinde de İstanbul BB’nin diğer BB'lere oranla daha yüksek paylaşım oranlarına sahip olduğu görülmektedir.

Şekil 1'de araştırma kapsamındaki BB'lerin "kaynağına göre tercih ettikleri paylaşım şekilleri” görülmektedir. $\mathrm{Bu}$ şekilde BB'lerin paylaşımları "doğrudan BB hesabından yapılan paylaşımlar”, "BB başkanının paylaşımlarının retweet edilmesi (yeniden paylaşılması)” ve "diğer hesaplardan yapılan paylaşımların retweet edilmesi (yeniden paylaşılması)" şeklindeki paylaşımlar olarak üçe ayrılmıştır.

Buna göre, Ankara BB’nin araştırma döneminde 214 paylaşımının \%87,38’i (n=187) doğrudan BB hesabından yapılan paylaşımlar şeklinde ve \%12,62'si $(n=27)$ belediye başkanının paylaşımlarının retweet edilmesi şeklinde gerçekleşmiştir. Ankara BB tarafından belediye başkanı haricindeki kullanıcıların paylaşımlarının retweet edilmesi yöntemi hiç tercih edilmemiştir. Bu konuda İzmir BB’nin paylaşımları da Ankara BB’nin paylaşım oranlarına benzerlik göstermektedir. Buna göre, İzmir BB’nin paylaşımlarının \%96,44’ü ( $n=271)$ doğrudan kendi hesabından yapılan paylaşımlar, \%3,20'si $(n=9)$ belediye başkanının paylaşımlarının retweet edilmesi ve $\% 0,36$ 'sı $(n=1)$ diğer hesaplardan yapılan paylaşımların retweet edilmesi şeklinde gerçekleştirmiştir. Ankara ve İzmir BB'ye göre daha dengeli bir paylaşım oranına sahip olan İstanbul BB, paylaşımlarının \%43,35'ini $(\mathrm{n}=212)$ doğrudan kendi paylaşımları şeklinde, \%48,47'sini ( $\mathrm{n}=237$ ) belediye başkanının paylaşımlarının retweet edilmesi şeklinde ve $\% 8,18$ 'ini $(n=40)$ diğer hesaplardan yapılan paylaşımların retweet edilmesi şeklinde gerçekleştirmiştir. 


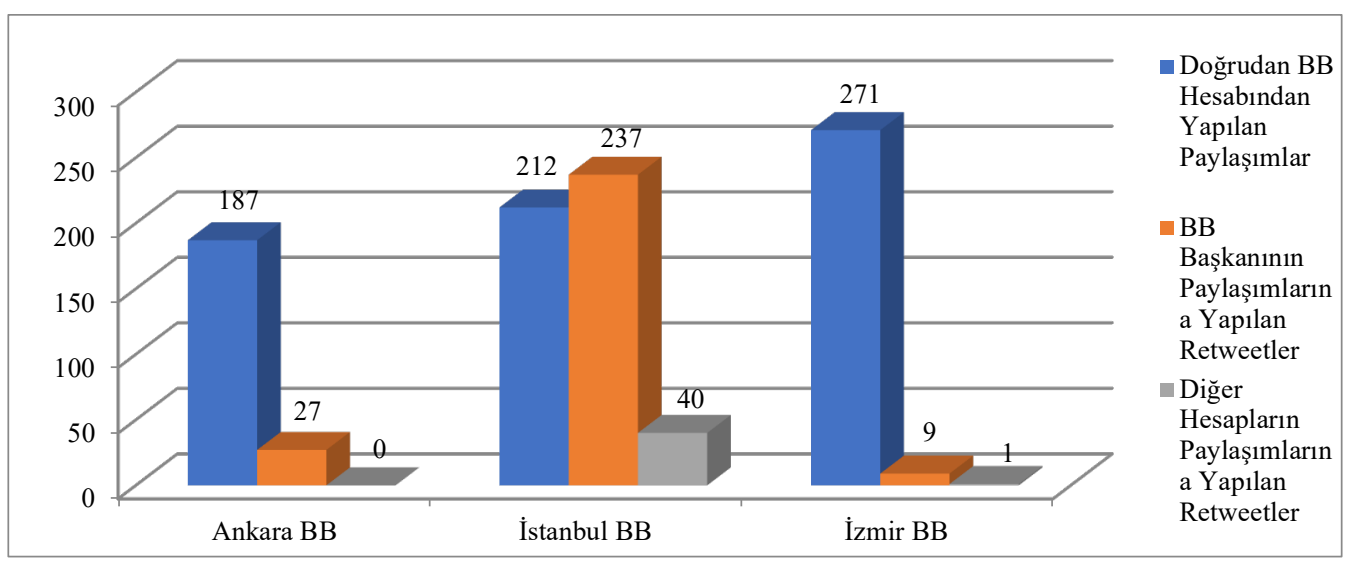

\section{Şekil 1. Paylaşımların Kaynağına Göre Dă̆ılımı}

$\mathrm{Bu}$ oranlarla bağlantılı olarak, Ankara BB tarafından yapılan paylaşımların \%12,62'si ( $\mathrm{n}=27)$, İzmir BB tarafından yapılan paylaşımların \%3,20'si ( $\mathrm{n}=9$ ) BB başkanının kendi hesabından yapılan paylaşımların retweet edilmesi şeklindeki paylaşımlar olmasına rağmen, İstanbul BB'de bu oran \%48,47 ( $\mathrm{n}=237$ ) olarak gerçekleşmiştir. Bu oranlar, İstanbul BB paylaşımlarında BB başkanının yapmış olduğu paylaşımların retweet edilmesi yolu ile hizmet ve faaliyetlerin duyurulması yönteminin oldukça fazla kullanmakta olduğunu göstermektedir.

\section{Takipçilerin Tepkileri İle İlgili Bulgular}

Tablo 4'te BB'lerin Twitter paylaşımlarının kaynaklarına göre ayrımı ve takipçilerin bu paylaşımlara "beğeni”, "retweet" ve "yorum” şeklinde verdikleri tepkilerin ortalama değerleri görülmektedir. Buna göre, toplam paylaşımlarda İstanbul BB paylaşım başına ortalama 558,01 beğeni, 151,24 retweet ve 26,30 yorum ortalamaları ile en yüksek değerlere sahiptir. Toplam paylaşımlar kategorisinde İzmir BB 348,49 beğeni, 56,78 retweet ve 12,06 yorum ortalamasıyla ikinci en yüksek değerlere sahip olan BB'dir.

Tablo 4. Paylaşımların Kaynağına Göre Ortalama Beğeni, Retweet ve Yorum Sayıları

\begin{tabular}{|c|c|c|c|c|}
\hline & & Ankara BB & İstanbul BB & İzmir BB \\
\hline \multirow{3}{*}{$\begin{array}{l}\text { Doğrudan Belediye } \\
\text { Hesabından Paylaşımlar }\end{array}$} & $\begin{array}{l}\text { Ortalama } \\
\text { Beğeni Sayısı }\end{array}$ & 107,80 & 215,60 & 125,60 \\
\hline & $\begin{array}{l}\text { Ortalama } \\
\text { Retweet Sayıs1 }\end{array}$ & 22,07 & 76,72 & 25,64 \\
\hline & $\begin{array}{l}\text { Ortalama } \\
\text { Yorum Sayısı }\end{array}$ & 4,99 & 7,85 & 7,06 \\
\hline \multirow{3}{*}{$\begin{array}{l}\text { BB Başkanının } \\
\text { Paylaşılarının Retweet } \\
\text { Edilmesi }\end{array}$} & $\begin{array}{l}\text { Ortalama } \\
\text { Beğeni Sayıs1 } \\
\end{array}$ & 404,96 & 349,02 & $6.977,67$ \\
\hline & $\begin{array}{l}\text { Ortalama } \\
\text { Retweet Sayıs1 }\end{array}$ & 85,48 & 93,95 & 979,44 \\
\hline & $\begin{array}{l}\text { Ortalama } \\
\text { Yorum Sayıs1 }\end{array}$ & 20,56 & 16,00 & 159,67 \\
\hline \multirow{3}{*}{$\begin{array}{l}\text { Diğer Hesapların } \\
\text { Paylaşımlarının Retweet } \\
\text { Edilmesi }\end{array}$} & $\begin{array}{l}\text { Ortalama } \\
\text { Beğeni Sayıs1 }\end{array}$ & 0,00 & $3.611,08$ & $1.090,00$ \\
\hline & $\begin{array}{l}\text { Ortalama } \\
\text { Retweet Sayıs1 }\end{array}$ & 0,00 & 885,55 & 190,00 \\
\hline & $\begin{array}{l}\text { Ortalama } \\
\text { Yorum Sayıs1 }\end{array}$ & 0,00 & 185,08 & 38,00 \\
\hline \multirow{3}{*}{ Toplam Paylaşımlar } & $\begin{array}{l}\text { Ortalama } \\
\text { Beğeni Sayıs1 }\end{array}$ & 145,29 & 558,01 & 348,49 \\
\hline & $\begin{array}{l}\text { Ortalama } \\
\text { Retweet Sayıs1 }\end{array}$ & 30,07 & 151,24 & 56,78 \\
\hline & $\begin{array}{l}\text { Ortalama } \\
\text { Yorum Sayıs1 }\end{array}$ & 6,96 & 26,30 & 12,06 \\
\hline
\end{tabular}


İstanbul BB'nin “doğrudan belediye hesabından yapılan paylaşımları” ortalama 215,60 beğeni, 76,72 retweet ve 7,85 yorum alarak, diğer iki BB'den daha yüksek değerlere sahip olmuştur. "Doğrudan belediye hesabından yapılan paylaşımlar" kategorisindeki paylaşımların tamamında İzmir BB ikinci sırayı almaktadır. "Belediye başkanının paylaşımlarına yapılan retweetler” şeklindeki paylaşımlarda ise, İzmir BB’nin paylaşımlarının 6.977,67 beğeni, 979,4 retweet ve 159,67 yorum ortalaması ile diğer BB'lere oranla oldukça yüksek değerlere sahip olduğu görülmektedir. "Diğer hesapların paylaşımlarına yapılan retweetler" kategorisinde ise, İstanbul BB 3.611,08 beğeni, 885,55 retweet ve 185,08 yorum ortalamaları ile en çok etkileşime girilen BB olmuştur. Ankara BB araştırma döneminde BB başkanı dışında hiçbir hesaptan yapılan paylaşımları retweet yapmamıştır.

BB paylaşımlarının kaynaklarına göre yapılan ayrım kendi içinde de birbirinde farklı sonuçlar ortaya koymaktadır. Buna göre, Ankara BB'nin "BB başkanının paylaşımlarının retweet edilmesi” şeklindeki paylaşımları "doğrudan BB hesabından yapılan paylaşımları"na oranla yaklaşık dört (4) kat daha fazla beğeni ortalamasına sahiptir. İzmir BB’nin paylaşımlarında ise, "BB başkanının paylaşımlarının retweet edilmesi" şeklindeki paylaşımların "doğrudan BB hesabından yapılan paylaşımlar"a oranla 50 kattan daha fazla beğeni ortalamasına sahip olduğu görülmektedir. İstanbul BB'de de fark bu kadar olmasa da "BB başkanının paylaşımlarının retweet edilmesi” şeklindeki paylaşımlar daha yüksek beğeni ortalamasına sahip olmaktadır.

İstanbul BB'nin "diğer hesapların paylaşımlarına yapılan retweetler" şeklindeki paylaşımları "doğrudan BB hesabından yapılan paylaşımlar" ve "BB başkanının paylaşımlarına yapılan retweetler” şeklindeki paylaşımlarından on (10) kattan fazla beğeni almaktadır. İzmir BB'nin "BB başkanının paylaşımlarına yapılan retweetler" şeklindeki paylaşımlarının ortalama beğenilme oranlarının oldukça yüksek olduğu (6.977,67 beğeni) görülmektedir. Bu dağılım, Ankara ve İzmir BB’lerinin "BB başkanlarının paylaşımlarına yapılan retweetler” şeklindeki paylaşımlarının diğer paylaşım şekillerine göre daha fazla beğeni aldığı, İstanbul BB'nin ise "diğer hesapların paylaşımlarına yapılan retweetler" şeklindeki paylaşımlarının daha fazla beğeni aldığını ortaya koymaktadır. BB'lerin paylaşımlarına yapılan ortalama yorum ve retweet sayıları itibariyle de ortalama beğeni sayılarına benzer bir dağılım görülmektedir.

Şekil 2'de BB'lerin sektörlere ve sektör dışı faaliyet alanlarına göre paylaşımları başına düşen beğeni ortalamaları (BB’lerin retweet paylaşımları dâhil) görülmektedir. Buna göre, sektörlerle ilgili paylaşımlar kategorisinde Ankara BB'nin paylaşımları ortalama140,14 beğeni, İstanbul BB’nin paylaşımları 464,46 beğeni ve İzmir BB’nin paylaşımları 386,16 beğeni almıştır. Herhangi bir sektörle ilgili olmayan faaliyet alanlarındaki paylaşımlarda ise, Ankara BB'nin paylaşımları 158,21 beğeni, İstanbul BB'nin paylaşımları 836,40 beğeni ve İzmir BB’nin paylaşımları 264,51 beğeni almıştır. Görüldüğü üzere, hem sektörlerle ilgili paylaşımlarda hem de sektör dışı faaliyetlerle ilgili paylaşımlarda İstanbul BB'nin paylaşımları diğer BB'lere oranla daha fazla beğeni ortalamasına sahiptir. Bu kategoride tüm BB'lerin paylaşımlarına takipçilerin verdikleri "retweet" ve "yorum" şeklindeki tepkiler de de İstanbul BB en yüksek değerlere sahip olmuş; İstanbul BB’yi İzmir BB izlemiş̧tir.

Ankara BB’nin 245,50 ortalama beğeniye sahip "medya ve haber" sektörleri ve 317,40 ortalama beğeniye sahip "sağılı ve spor" sektörlerinde yaptığı paylaşımlar diğer BB'lerin bu sektörlerde yaptıkları paylaşımlardan daha yüksek ortalama beğeni sayılarına ulaşmıştır. İzmir BB'nin 
493,88 ortalama beğeniye sahip "kentsel planlama ve dönüşüm”, 150,00 ortalama beğeniye sahip "metroloji ve iklim" ve 2.313,36 ortalama beğeniye sahip "park, yeşil alan ve çevre" sektörlerinde yaptığı paylaşımlar bu alanlarda diğer BB’lerin paylaşımlarından daha fazla ortalama beğeniye sahip olmuştur. Geri kalan 14 sektör veya faaliyet alanında İstanbul BB'nin paylaşımları diğer BB'lerden daha yüksek beğeni ortalamalarına sahip olmuştur. Bu sektörlerden 820,79 ortalama beğeni sayısına ulaşan "atık, arıtma, geri dönüşüm ve temizlik sektörleri” ve 807,66 ortalama beğeniye sahip "ulaşım, trafik ve toplu taşıma” sektörleri en yüksek beğeniye sahip sektörler olarak dikkat çekmektedir.

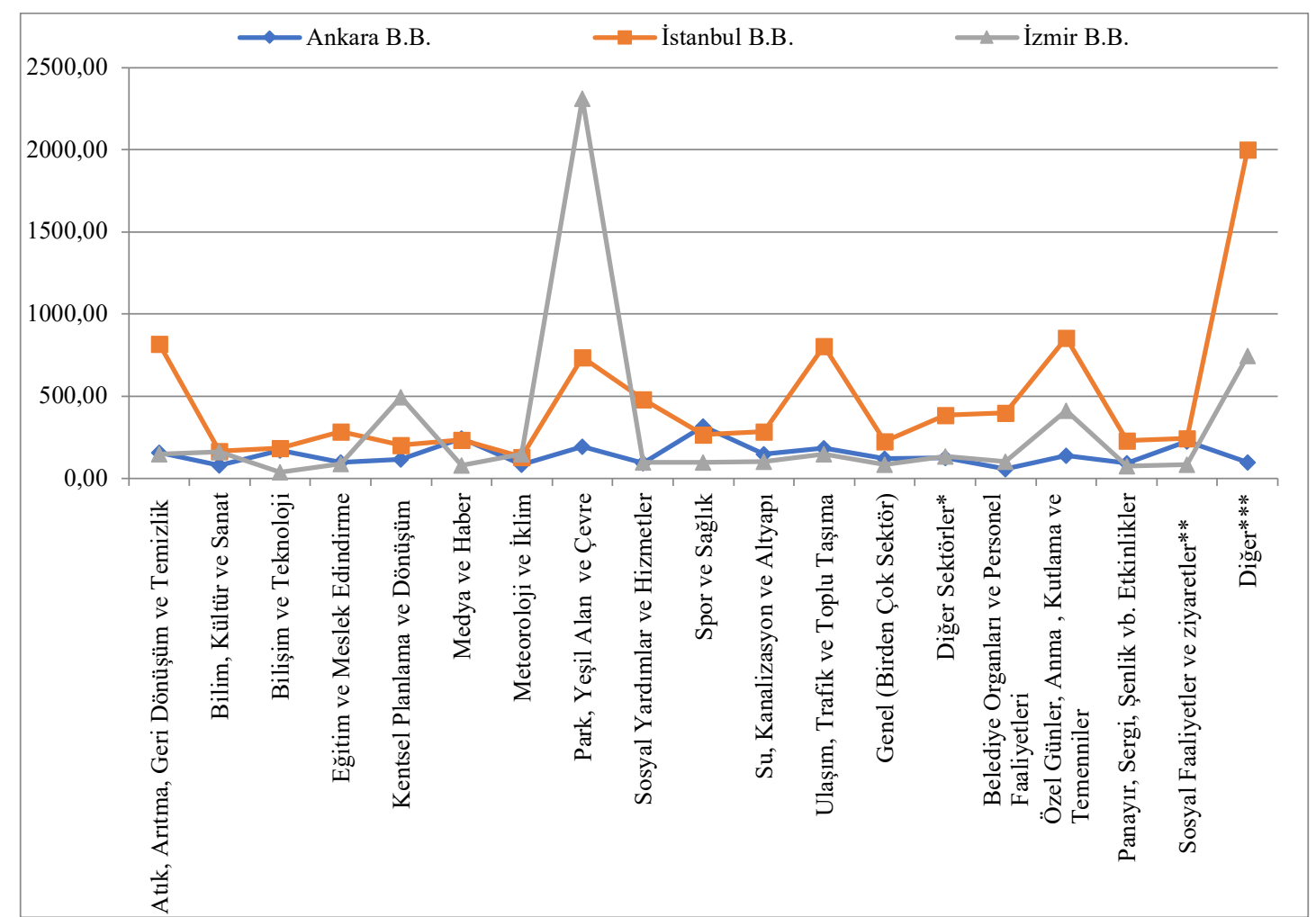

*(Tarım, Turizm, İl Tanıtımı, Sokak Hayvanları, Gıda, Enerji)

**(Cenaze, Nikah, Düğün vb.)

***(Denetimler, Cezalar, Doğal ve Tabi Afetler ve Diğer Etkinlikler)

Şekil 2: Sektörlere ve Sektör Dışı Faaliyet Alanlarına Göre Paylaşım Başına Düşen Beğeni Ortalamaları (BB’lerin Retweet Paylaşımları Dahil)

Ankara BB'nin paylaşımlarından en çok ortalama beğeni “spor ve sağlık” sektörüyle ilgili paylaşımlara yapılmıştır. Bu sektörlerde yapılan beş (5) paylaşım toplamda 1.587 beğeni alarak, paylaşım başına 317,40 beğeni ortalamasına sahip olmuştur. İstanbul BB'nin en çok ortalama beğeni alan paylaşımları "diğer (denetimler, cezalar, doğal ve tabi afetler ve diğer etkinlikler)" alanı olmuştur. Bu alanda yapılan 26 paylaşım toplamda 52.307 beğeni alarak paylaşım başına 2.001 beğeni ortalamasına sahip olmuştur. İzmir BB’nin paylaşımlarında ise en çok beğeni alan sektör "park, yeşil alan ve çevre" sektörleri olmuştur. Bu alanda paylaşım başına 2.313,36 beğeni düşmektedir.

Ankara BB'nin yapmış olduğu paylaşımlardan en çok beğeni ortalamasına sahip "spor ve sağlık" sektörlerinden sonra, ikinci sırada "medya ve haber" sektörü gelmektedir. "Medya ve haber" sektöründe altı (6) paylaşım 1.473 beğeni alarak paylaşım başına 245,50 beğeni almıştır. İstanbul BB’nin paylaşımlarından ikinci en yüksek beğeni ortalaması “özel günler, anma, kutlama ve 
temenniler” alanında gerçekleşmiş olup, bu alanda yapılan 26 paylaşıma toplamda 35,129 beğeni yapılmış ve paylaşım başına 856,80 beğeni düşmüştür. İzmir BB paylaşımlarında ise ikinci en yüksek beğeni ortalaması "diğer (denetimler, cezalar, doğal ve tabi afetler ve diğer etkinlikler)" faaliyet alanlarında gerçekleşmiştir.

Şekil 3'te BB'lerin retweet paylaşımları dahil edilmeden doğrudan kendi hesaplarından yaptıkları paylaşımların beğeni ortalamaları görülmektedir. Buna göre, toplamda Ankara BB'nin 187 doğrudan kendi hesabından paylaşımı 20.159 beğeni alarak 107,80 ortalama beğeniye; İstanbul BB'nin 212 doğrudan kendi hesabından paylaşımı 45.708 beğeni alarak 215,60 ortalama beğeniye ve İzmir BB'nin 271 doğrudan kendi hesabından paylaşımı 34.038 beğeni alarak 125,60 ortalama beğeniye sahip olmuştur. Bu değerler BB’lerin retweet yapmak suretiyle yaptıkları paylaşımların toplam beğeni ortalamalarını arttırdığını ortaya koymaktadır. Şekil 2'de görüleceği üzere, retweetler dâhil edilerek yapılan analizde Ankara BB paylaşım başına 145,29 ortalama beğeniye, İstanbul BB 558,01 ortalama beğeniye ve İzmir BB 348,49 ortalama beğeniye sahip olurken, BB'lerin doğrudan kendi hesaplarından yaptıkları paylaşımlar daha düşük beğeni ortalamalarına sahiptir.

Şekil 3'te Ankara BB'nin retweet paylaşımları dâhil edilmeden doğrudan kendi hesabından yaptığ paylaşımlarda 170,67 ortalama beğeniye sahip "bilişim ve teknoloji” sektörleri, 265,25 ortalama beğeniye sahip "medya ve haber" sektörleri ve 92,67 ortalama beğeniye sahip "fuar, panayır, sergi, şenlik vb. her türlü etkinlikler” alanlarıyla ilgili paylaşımları diğer BB’lerin bu sektörlerdeki/sektör dışı faaliyet alanlarındaki paylaşımlarından daha fazla ortalama beğeni sayılarına ulaştığı görülmektedir. İzmir BB’nin paylaşımlarında ise, 149,50 ortalama beğeniye sahip "kentsel planlama ve dönüşüm" sektörleri, 137,00 ortalama beğeniye sahip "meteoroloji ve iklim” sektörleri ve 281,71 ortalama beğeniye sahip “özel günler, anma, kutlama ve temenniler” faaliyet alanları ile ilgili paylaşımlar diğer BB’lerin bu sektör/sektör dışı faaliyet alanlarındaki paylaşımlarından daha fazla ortalama beğeniye sahip olmuştur. BB’lerin retweet paylaşımları dâhil edilmeden doğrudan kendi hesabından yaptığı paylaşımlarda Ankara ve İzmir BB'leri üçer sektör gurubunda/sektör dışı faaliyet alanlarında en fazla ortalama beğeniye sahip olurken, geri kalan 13 sektör grubunda /sektör dışı faaliyet alanında en fazla ortalama beğeniye İstanbul BB sahip olmuştur.

Şekil 3’te görüldüğü üzere, retweet paylaşımlar dahil edilmeden BB’lerin doğrudan kendi hesaplarından yaptığı paylaşımların beğeni ortalamaları retweet paylaşımlar dahil edilerek hesaplanan beğeni ortalamalarına (Şekil 2) oranla daha düşük seviyelerde kalmaktadır. Özellikle İzmir BB’nin “park, yeşil alan ve çevre” sektörlerindeki paylaşımları ve İstanbul BB’nin "diğer (denetimler, cezalar, doğal ve tabi afetler ve diğer etkinlikler)" faaliyet alanlarında yaptığ paylaşımlarda görüldüğü gibi ortalama 2.000 beğeniyi geçen paylaşımlara hiç rastlanmamaktadır. 


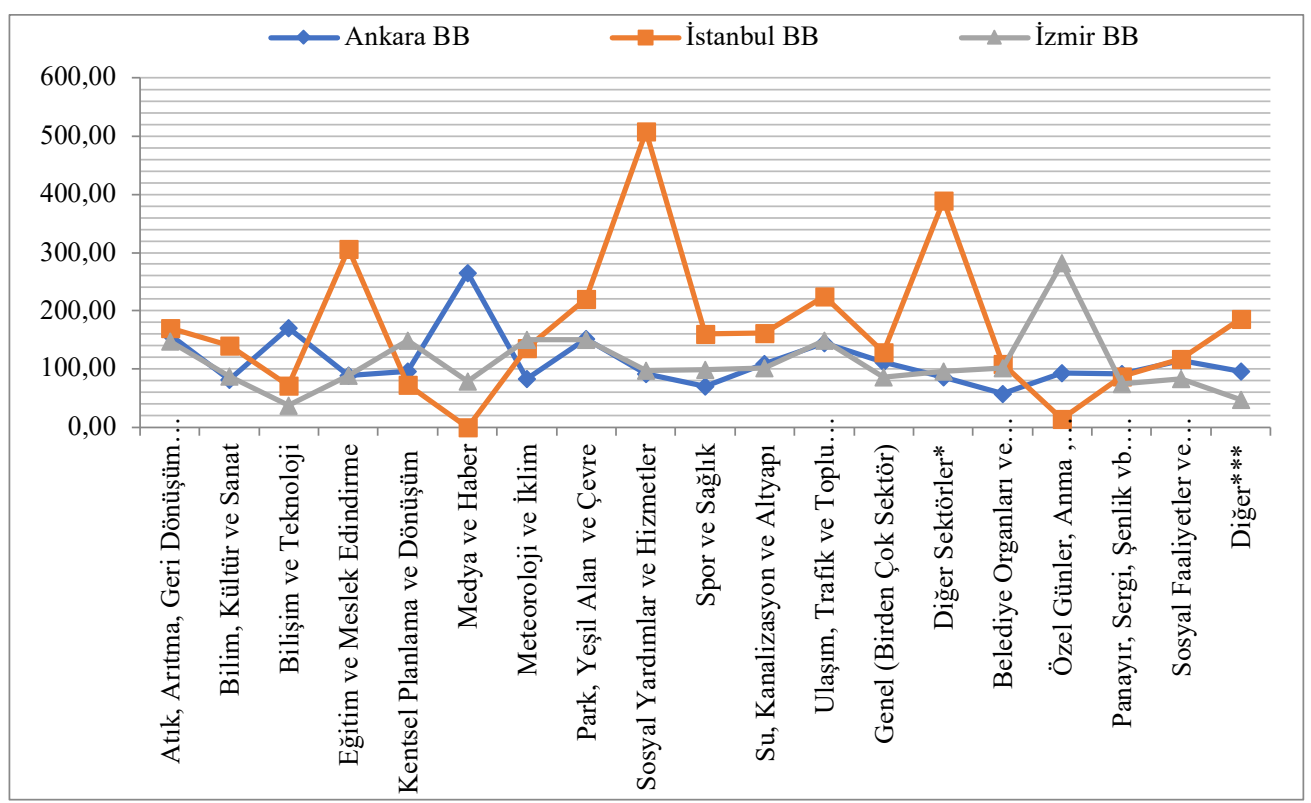

*(Tarım, Turizm (İl Tanıtımı), Sokak Hayvanları, Gıda, Enerji)

**(Cenaze, Nikah, Dügün vb.)

***(Denetimler, Cezalar, Doğal ve Tabi Afetler ve Diğer Etkinlikler)

Şekil 3. Sektörlere ve Sektör Dışı Faaliyet Alanlarına Göre Paylaşım Başına Düşen Beğeni Ortalamaları (BB'lerin Retweet Paylaşımları Hariç)

Şekil 4'te BB'lerin retweet paylaşımları dâhil edilerek sektörlere ve sektör dışı faaliyet alanlarına göre paylaşım başına düşen ortalama yorum sayıları görülmektedir. Buna göre, Ankara BB'nin toplam 214 paylaşımına 1.489 yorum yapılarak 6,96 yorum ortalaması, İstanbul BB'nin 489 paylaşımına 12.860 yorum yapılarak 26,30 yorum ortalaması ve İzmir BB’nin 281 paylaşımına 3.389 yorum yapılarak 12,06 yorum ortalaması elde edilmiştir. Görüldüğü üzere, paylaşım başına düşen ortalama yorum sayılarında da BB'ler arasındaki sıralama "beğeni" ortalamalarındaki ile aynı şekilde oluşmuş, yüksekten başlamak üzere İstanbul BB, İzmir BB ve Ankara BB şeklinde gerçekleşmiştir.

Sektörlere göre değerlendirildiğinde ise, Ankara BB'nin paylaşım başına ortalama 8,78 yorum yapılan "bilişim ve teknoloji", 5,18 yorum yapılan "meteoroloji ve iklim" ve 14,60 yorum yapılan "spor ve sağlık" sektör gruplarındaki paylaşımlarının diğer BB’lerden daha fazla ortalama yorum sayısına sahip olduğu görülmektedir. İzmir BB’nin ise, paylaşım başına ortalama 8,37 yorum yapılan "bilim, kültür ve sanat", 22,25 yorum yapılan "kentsel planlama ve dönüşüm”, 9,62 yorum yapılan "genel (birden çok sektör)" ve 41,20 yorum yapılan "belediye organları ve personel faaliyetleri” sektör grupları veya sektör dışı faaliyet alanlarında yaptığı paylaşımlara diğer BB'lerden daha fazla yorum yapılmıştır. Geri kalan 12 sektör grubu veya faaliyet alanında İstanbul BB'nin paylaşımları diğer iki BB’nin paylaşımlarından daha fazla yorum almıştır.

Özellikle, “özel günler, anma, kutlama ve temenniler” faaliyet alanlarında İzmir BB’nin paylaşımları ortalama 4,47 ve Ankara BB'nin paylaşımları ortalama 3,19 yorum almasına rağmen İstanbul BB’nin paylaşımları ortalama 43,22 yorum almış ve diğer BB'lerin paylaşımlarından oldukça yüksek bir ortalama değere sahip olmuştur. Benzer şekilde "panayır, 
sergi, şenlik vb etkinlik” faaliyetleriyle ilgili paylaşımlarda Ankara BB'nin paylaşım başına ortalama 0,33 yorum ve İzmir BB’nin 1,68 yorum almasına karşılık İstanbul BB’nin paylaşımları 14,67 ortalama yorum almıştır. Bu faaliyet alanlarına ilave olarak "atık, arıtma, geri dönüşüm ve temizlik", "eğitim ve meslek edindirme" "sosyal yardımlar ve hizmetler" ve "diğer sektörler”de de İstanbul BB’nin diğer BB’lere oranla oldukça yüksek yorum ortalamalarına sahip olduğu görülmektedir.

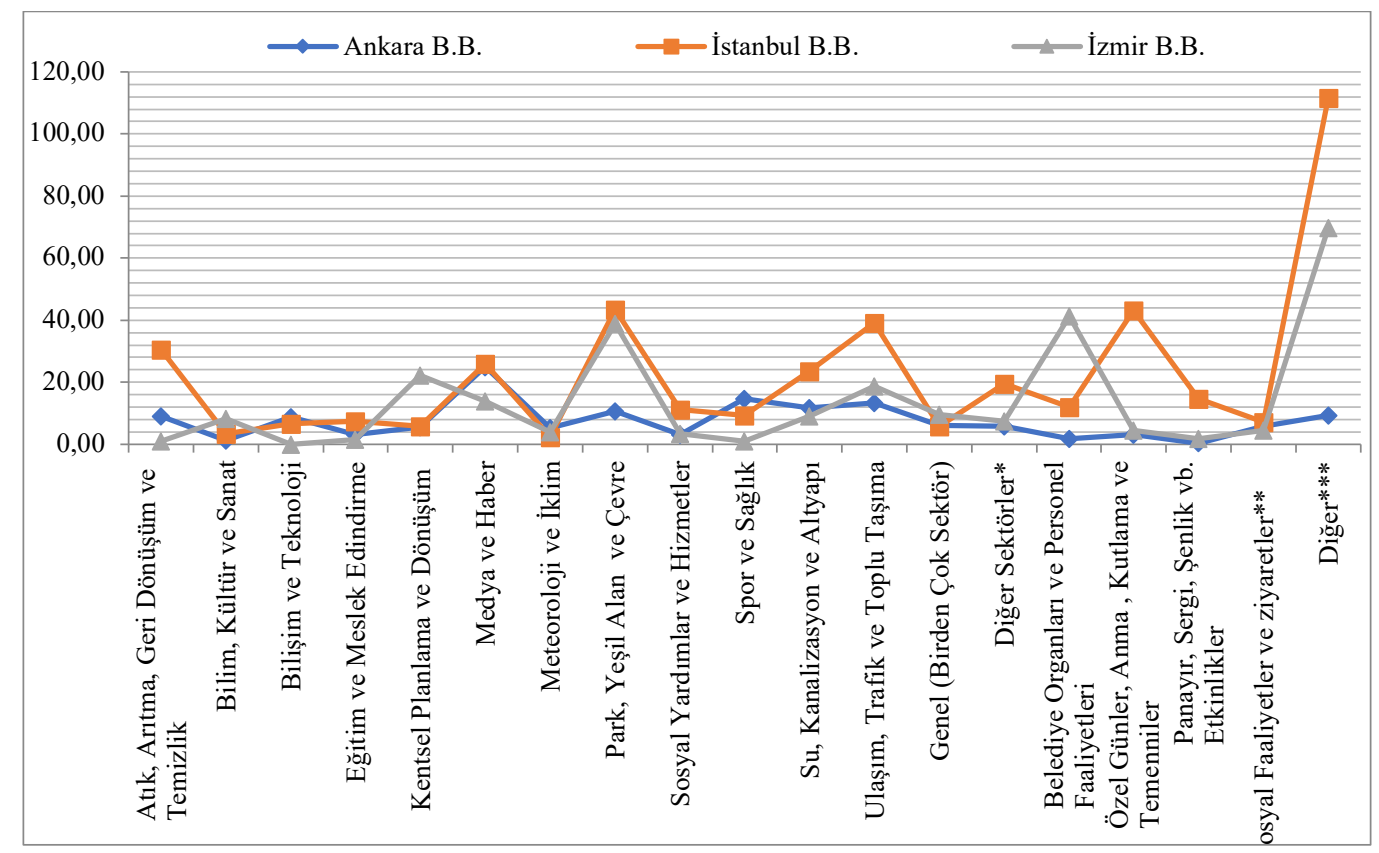

*(Tarım, Turizm (İl Tanıtımı), Sokak Hayvanları, Gıda, Enerji)

**(Cenaze, Nikah, Düğün vb.)

***(Denetimler, Cezalar, Doğal ve Tabi Afetler ve Diğer Etkinlikler)

Şekil 4. Sektörlere ve Sektör Dışı Faaliyet Alanlarına Göre Paylaşım Başına Düşen Yorum Ortalamaları (BB'lerin Retweet Paylaşımları Dahil)

Şekil 5'te BB'lerin retweet paylaşımları dâhil edilmeden doğrudan kendi hesaplarından yaptıkları paylaşımların sektörlere ve faaliyet alanlarına göre ortalama yorum sayıları görülmektedir. Bu dağılımda İstanbul BB’nin ortalama değerlerinin yüksekliği devam etmekle birlikte Şekil 2, Şekil 3 ve Şekil 4'teki ortalama değerlerdeki yüksek oranlar kısmen azalma eğilimi göstermiştir. Ortalama yorum sayılarında Ankara BB’nin paylaşımları beş (5), İzmir BB'nin paylaşımları altı (6) sektör veya sektör dışı hizmet alanında en yüksek yorum oranına sahip olurken, İstanbul BB'nin paylaşımları sekiz (8) sektör veya faaliyet alanında en yüksek yorum ortalamalarına sahip olmuştur. Buna göre, Ankara BB'nin “atık, arıtma, geri dönüşüm ve temizlik" sektörlerindeki paylaşımları ortalama 9,00, "bilişim ve teknoloji” sektörlerindeki paylaşımları 8,78, "medya ve haber" sektörlerindeki paylaşımları 23,25, "meteoroloji ve iklim" sektörlerindeki paylaşımları 5,18 ve "park, yeşil alan ve çevre" sektörlerindeki paylaşımları 11,40 ortalama yorum alarak diğer BB'lerin bu sektörlerdeki paylaşımlarına yapılan yorumlardan daha fazla yorum ortalamalarına sahip olmuştur. 


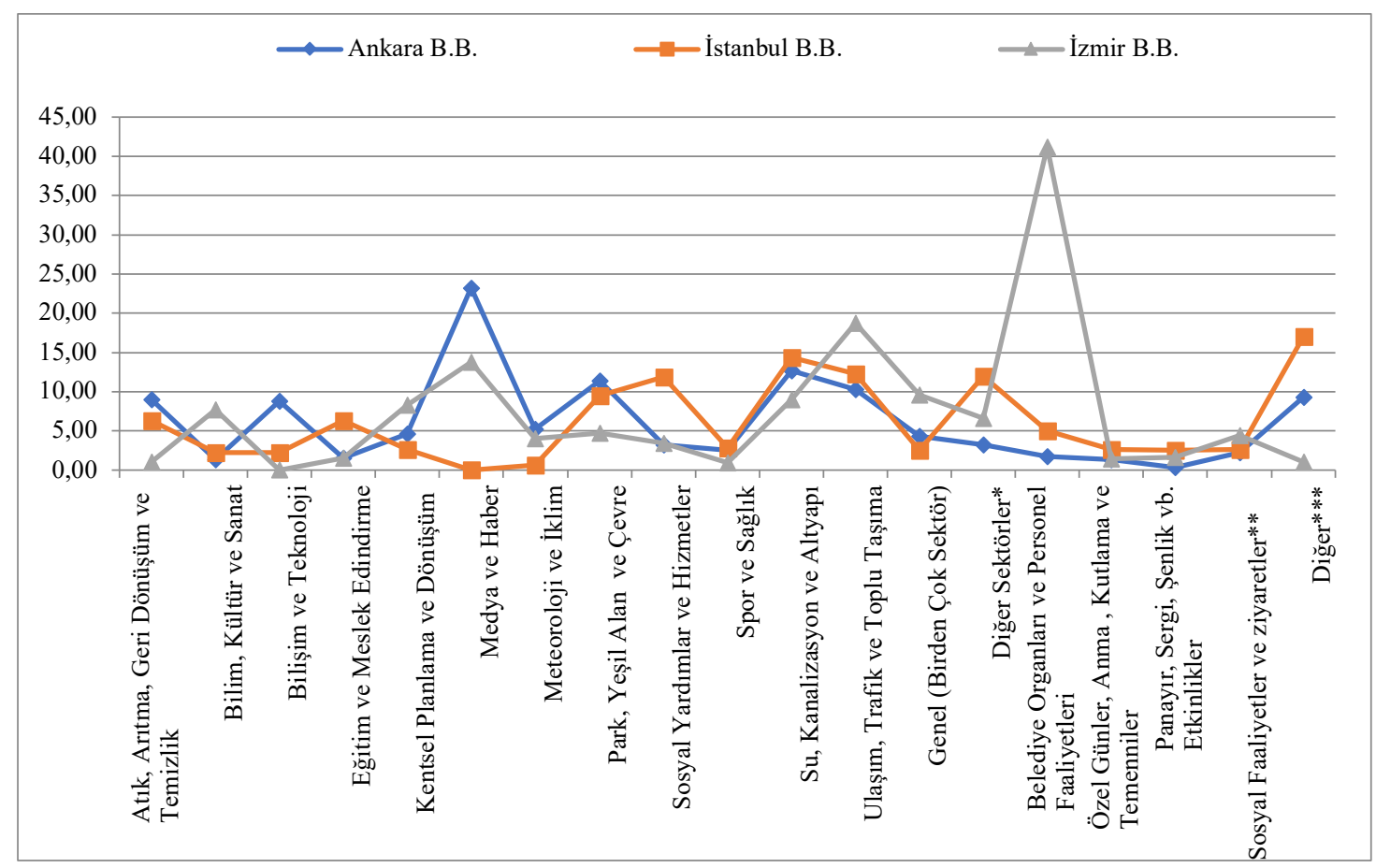

*(Tarım, Turizm (İl Tanıtımı), Sokak Hayvanları, Gıda, Enerji)

**(Cenaze, Nikah, Düğün vb.)

***(Denetimler, Cezalar, Doğal ve Tabi Afetler ve Diğer Etkinlikler)

Şekil 5. Sektörlere ve Sektör Dışı Faaliyet Alanlarına Göre Paylaşım Başına Düşen Yorum Sayıları (BB'lerin Retweet Paylaşımları Hariç)

İzmir BB’nin "bilim, kültür ve sanat" sektörlerindeki paylaşımları ortalama 7,66, "kentsel planlama ve dönüşüm" sektörlerindeki paylaşımları 8,33, "ulaşım, trafik ve toplu taşıma" sektörlerindeki paylaşımları 18,70, "genel (birden çok sektör)" paylaşımları 9,62, "belediye organları ve personel faaliyetleri" alanındaki paylaşımları 41,20 ve "sosyal faaliyetler ve ziyaretler" alanındaki paylaşımları 4,39 ortalama yorum olarak diğer BB'lerden daha fazla ortalama yorum sayılarına sahip olmuştur. Ankara ve İzmir BB'lerinin en yüksek ortalama yorum sayılarına ulaştığı onbir (11) sektör veya faaliyet alanı dışında kalan sekiz sektör veya sektör dışı faaliyet alanında İstanbul BB paylaşımları en yüksek ortalama yorum sayılarına ulaşmıştır.

Şekil 6'da BB'lerin doğrudan kendi hesaplarından yaptıkları paylaşımların takipçiler tarafından retweet edilme ortalamaları görülmektedir. Bu şekilde en çok dikkate değer konulardan biri, İstanbul BB tarafından yapılan paylaşımların retweet oranlarındaki yüksekliktir. Şekil 6’ya göre, Ankara BB'nin "bilişism ve teknoloji” sektörlerindeki paylaşımları 44,00 ve "medya ve haber" sektörlerindeki paylaşımları 74,25 retweet ortalamasına sahip olarak, diğer BB'lerden daha yüksek ortalama değerlere ulaşmıştır. İzmir BB'nin ise, "meteoroloji ve iklim” sektörlerindeki paylaşımları 67,00 ve "özel günler, anma, kutlama ve temenniler" alanlarındaki paylaşımları 55,50 retweet ortalamasına sahip olarak diğer BB'lerden daha yüksek ortalama değerlere ulaşmıştır. Geri kalan 15 sektör veya faaliyet alanında İstanbul BB'nin paylaşımları diğer BB'lerin paylaşımlarından daha fazla retweet ortalamasına sahip olmuştur. İstanbul BB'nin özellikle "bilim, kültür ve sanat", "eğitim ve meslek edindirme", "park, yeşil alan ve çevre", "sosyal yardımlar ve hizmetler" ve "diğer sektörler" sektörleri veya faaliyet alanlarındaki 
paylaşımları diğer BB'lerin bu alanlardaki paylaşımlarından en az üç kat daha fazla retweet edilmesi İstanbul BB tarafından yapılan paylaşımların retweet oranlarının yüksekliğine örnek teşkil etmektedir.

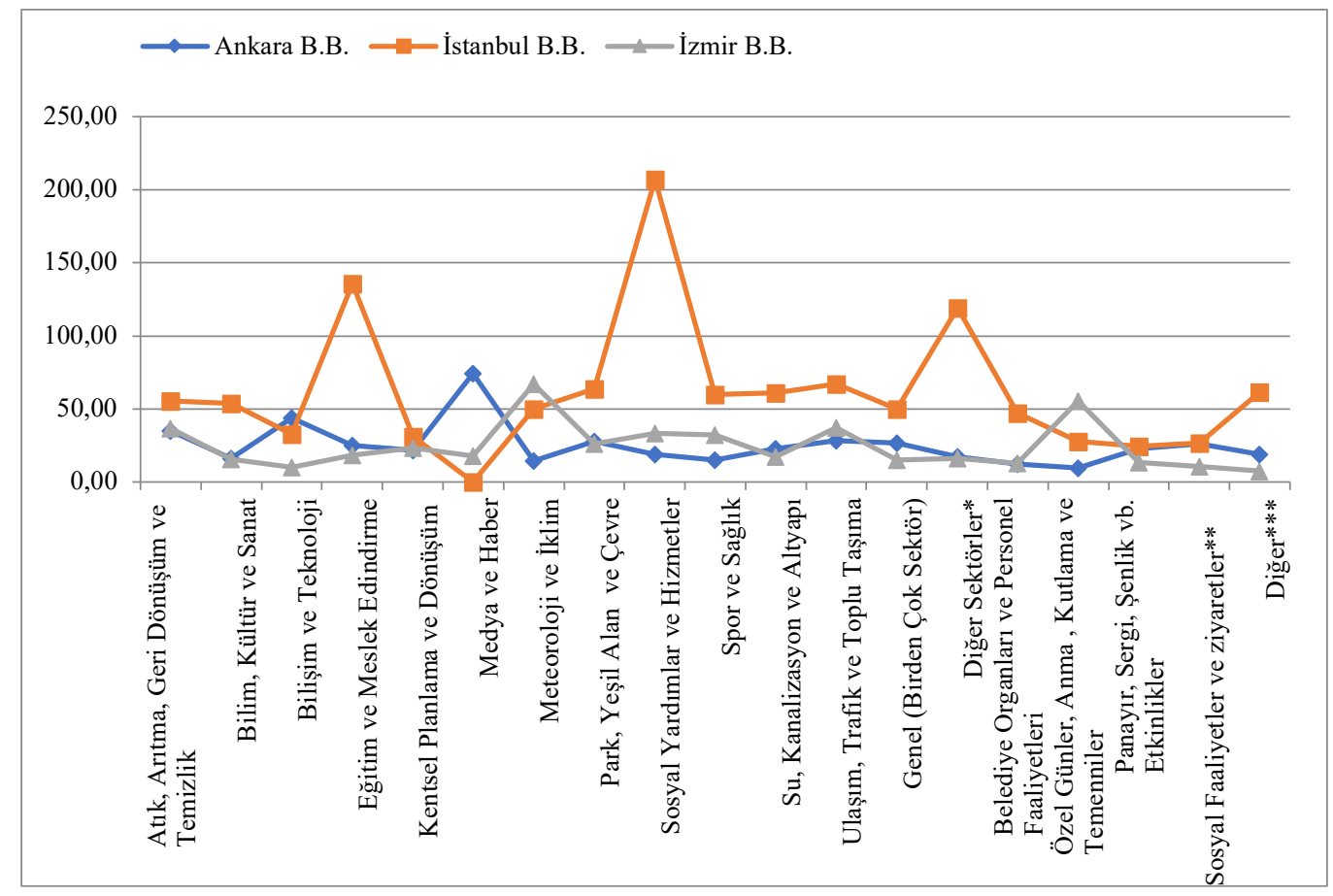

*(Tarım, Turizm (İl Tanıtımı), Sokak Hayvanları, Gıda, Enerji)

**(Cenaze, Nikah, Düğün vb.)

***(Denetimler, Cezalar, Doğal ve Tabi Afetler ve Diğer Etkinlikler)

Şekil 6. Sektörlere ve Sektör Dıșı Faaliyet Alanlarına Göre Paylaşım Başına Düsşen ortalama Retweet Sayıları

Toplam paylaşım sayılarının toplam retweet sayılarına oranı da İstanbul BB’nin paylaşımlarının yüksek retweet oranlarını ortaya koymaktadır. Buna göre, Ankara BB’nin doğrudan kendi hesabından yaptığı 187 paylaşım kullanıcılar tarafından 4.127 retweet edilerek ortalama 22,07 retweet oranına sahip olmasına ve İzmir BB’nin doğrudan kendi hesabından yaptığı 271 paylaşım 6.949 retweet edilerek ortalama 25,64 retweet oranına sahip olmasına rağmen İstanbul BB'nin kendi hesabından yaptığı 212 paylaşım 16,265 retweet edilerek 76,72 retweet ortalamasına sahip olmuştur. Bu oranlar, İstanbul BB takipçilerinin diğer BB’lerin takipçilerine göre paylaşımları daha çok retweet etme eğiliminde olduklarını ortaya koymaktadır. İstanbul BB'yi sırasıyla İzmir BB ve Ankara BB takip etmekle birlikte bu iki BB paylaşımlarının ortalama retweet oranları birbirlerine daha yakındır.

\section{Sonuç}

En yaygın sosyal medya platformlarından olan Twitter'in Ankara, İstanbul ve İzmir BB’leri tarafından kullanım eğilimleri ve takipçilerin paylaşımlara verdikleri tepkiler sosyal medyanın artan önemine bir örnek oluşturmaktadır. Her üç BB'nin takipçi sayıları sürekli artış eğiliminde olmakla birlikte, 19.02.2019 itibariyle Ankara BB’nin 552.294, İstanbul BB'nin 346.060 ve İzmir BB'nin 179.608 takipçisi bulunmaktadır. Takipçi sayısının il nüfusuna oranı itibariyle Ankara BB’nin diğer BB'lere oranla önemli bir üstünlüğü söz konusudur. BB'nin takipçi sayısının il nüfusuna oranı İstanbul'da \%2,30, İzmir'de \%4,16 olmasına rağmen Ankara'da bu 
oran \%10.03’tür. BB'lerin takipçi profilleri ve Ankara BB’nin takipçi oranındaki yüksekliğin sebepleri başka bir araştırmanın konusu olmakla birlikte, Ankara’nın başkent olması takipçi oranlarının artışına etki eden faktörlerden biri olduğu değerlendirilebilir.

Söz konusu BB’ler "takip ettikleri Twitter hesabı", "toplam paylaşım sayısı" ve "beğendikleri hesap sayısı" itibariyle değerlendirildiğinde ise, İstanbul BB'nin diğer belediyelerden daha aktif olduğu görülmektedir. Twitter'de resmi hesap açma tarihleri arasında çok uzun zaman olmamasına rağmen toplam paylaşım sayıları itibariyle İstanbul BB'nin İzmir BB'den yaklaşık 5 kat, Ankara BB'den 20 kat daha fazla paylaşım yapması İstanbul BB'nin Twitter'i diğer BB'lere göre daha aktif kullandığının somut örneğini oluşturmaktadır. Araştırma döneminde de (01.10.2018-31.12.2018) Ankara BB’nin 214, İstanbul BB’nin 489 ve İzmir BB'nin 281 paylaşımda bulunması bu sonucu destekler nitelikte bir veridir.

Araştırma konusu BB'lerin Twitter paylaşımları sektörlere ve sektör dışı faaliyet alanlarına göre incelendiğinde, İstanbul BB'nin daha çok bir sektör grubundaki faaliyetlere yönelik paylaşımlarda bulunduğu, Ankara ve İzmir BB'lerinin ise, daha çok sektör dışı faaliyetleri paylaşma yolunu tercih ettiği anlaşılmaktadır. Ankara BB tarafından yapılan paylaşımlarda "diğer sektörler (tarım, turizm, il tanıtımı, sokak hayvanları, gıda, enerji)", "metroloji ve iklim" ve "ulaşım, trafik ve toplu taşıma" sektörleri ön plana çıkarken; İstanbul BB'nin paylaşımlarında "spor ve sağllk", "ulaşım, trafik ve toplu taşıma" ve "park, yeşil alan ve çevre" sektörleri en çok paylaşım yapılan sektörler olmuştur. İzmir BB'nin paylaşımlarında ise, "ulaşım, trafik ve toplu taşıma", "bilim, kültür ve sanat" ve "genel (birden çok sektör)" sektörleri diğer sektörlerden daha çok paylaşıma konu olmuştur. "Ulaşım, trafik ve toplu taşıma"nın her üç BB'nin en çok paylaşım yaptığı sektörler arasında yer alması trafik ve ulaşım sektörlerinde BB'lerin karşılaşıtıları sorunlar ve bu sorunlara çözüm arayışlarıyla ilgili yapılan yoğun çalışmaların bir sonucu olduğu değerlendirilmelidir.

Sektör dışı faaliyetlerde her üç BB'de de “özel günler, anma kutlama, dilek ve temenniler" en çok paylaşım yapılan faaliyet alanları olmuştur. Bu faaliyetlerden Ankara ve İstanbul BB'de "sosyal faaliyetler ve ziyaretler" faaliyet alanları en çok paylaşım yapılan ikinci faaliyet alanı olurken, İzmir BB'de ise, en çok paylaşım yapılan ikinci faaliyet alanı "fuar, panayır, sergi, şenlik vb. etkinlikler" faaliyet alanları olmuştur.

Ankara BB’nin araştırma döneminde 214 paylaşımının \%87,38'i $(n=187)$ doğrudan BB hesabından yapılan paylaşımlar şeklinde ve \%12,62'si (n=27) belediye başkanının paylaşımlarının retweet edilmesi şeklinde gerçekleşmiştir. Belediye başkanı haricindeki kullanıcıların hesaplarından yapılan paylaşımlar Ankara BB tarafından retweet edilmemiştir. Bu konuda İzmir BB'nin paylaşımları da Ankara BB'nin paylaşım oranlarına benzerlik göstermektedir. Ankara ve İzmir BB'ye göre daha farklı bir yöntem izleyen İstanbul BB paylaşımlarının \%43,35'ini ( $\mathrm{n}=212)$ doğrudan kendi paylaşımları şeklinde, \%48,47'sini $(\mathrm{n}=237)$ belediye başkanının paylaşımlarının retweet edilmesi şeklinde ve $\% 8,18$ 'ini $(\mathrm{n}=40)$ diğer hesaplardan yapılan paylaşımların retweet edilmesi şeklinde gerçekleştirmiştir.

İstanbul BB tarafından doğrudan belediye hesabından yapılan paylaşımlar diğer BB'lerden daha fazla ortalama "beğeni", "retweet" ve "yorum" oranlarına sahiptir. Doğrudan belediye hesabından yapılan paylaşımların tamamında İzmir BB paylaşımları ikinci sırayı almaktadır. 
Belediye başkanının paylaşımlarına yapılan retweetler şeklindeki paylaşımlarda ise, İzmir BB'nin paylaşımlarının oldukça yüksek oranda ortalama beğeni, retweet ve yorum aldıkları görülmektedir. Ankara BB'nin “BB başkanının paylaşımlarının retweet edilmesi” şeklindeki paylaşımları "doğrudan BB hesabından yapılan paylaşımlar"dan yaklaşık dört (4) kat daha fazla beğeni ortalamasına sahiptir. İstanbul BB'nin “diğer hesapların paylaşımlarına yapılan retweetler" şeklindeki paylaşımları, "doğrudan BB hesabından yapılan paylaşımlar” ve "BB başkanının paylaşımlarına yapılan retweetler” şeklindeki paylaşımlardan on (10) kattan fazla beğeni almaktadır.

Retweet paylaşımları dahil edilerek BB'lerin paylaşımları başına düşen beğeni ortalamaları, Ankara BB'de 145,29, İstanbul BB'de 558.01, ve İzmir BB'de 348,49 beğenidir. Ancak, retweet paylaşımlar dâhil edilmeden BB'lerin doğrudan kendi hesaplarından yaptığı paylaşımların beğeni ortalamaları bu değerlere oranla daha düşük seviyelerde kalmaktadır. Sektörlere göre retweet paylaşımlar dahil olarak paylaşım başına düşen ortalama yorum sayılarında da BB'ler arasındaki sıralama "beğeni” ortalamalarındaki ile aynı şekilde gerçekleşmektedir. Buna göre, Ankara BB'de paylaşım başına 6,96 yorum, İstanbul BB'de 26,30 yorum ve İzmir BB'de 12,06 yorum ortalaması elde edilmiş; en yüksekten başlamak üzere İstanbul BB, İzmir BB ve Ankara BB şeklinde sırlama gerçekleşmiştir.

BB’lerin doğrudan kendi hesaplarından yaptıkları paylaşımların takipçiler tarafından retweet edilme ortalamalarında en yüksek oranlara İstanbul BB sahiptir. Buna göre, Ankara BB "bilişim ve teknoloji" ve "medya ve haber" sektörlerindeki paylaşımlarında yüksek retweet ortalamasıyla dikkat çekerken İzmir BB, "meteoroloji ve iklim" sektörlerinde ve "özel günler, anma, kutlama ve temenniler" alanlarındaki faaliyetlerle ilgili paylaşımlarda yüksek retweet ortalamasıyla dikkat çekmektedir. Geri kalan 15 sektör veya sektör dışı faaliyet alanında İstanbul BB’nin paylaşımları diğer BB'lerin paylaşımlarından daha fazla retweet ortalamasına sahip olmuştur.

\section{Kaynakça}

Bryer, T. A., Zavattaro, S. M. (2011). Social Media and Public Administration, Administrative Theory \& Praxis, 33(3). 325-340. doi: 10.2753/ATP1084-1806330301

Dadashzadeh, M. (2010). Social Media in Government: From eGovernment to eGovernance. Journal of Business \& Economics Research, 8(11), 81-86. doi: 10.19030/jber.v8i11.51

Ellison, N., Hardey, M. (2014). Social Media and Local Government: Citizenship, Consumption and Democracy, Local Government Studies, 40(1), 21-40. doi: 10.1080/03003930.2013.799066

Fillmore, A. C. C. (2012). Riding the Wave: Social Media in Local Government, New Hampshire Bar JournaL, Winter, 52(4). https://www.nhbar.org/wp-content/uploads/ fliphtml5/26/flipbook.html\#p=17

Graham, M.W., Avery, E. J., Park, S. (2015). The Role of Social Media in Local Government Crisis Communications. Public Relations Review, 41, 386-394. http://dx.doi.org/10.1016/j.pubrev.2015.02.001 
Gao, X., Lee, J. (2017). E-government services and social media adoption: Experience of small local governments in Nebraska state, Government Information Quarterly, 34 (2017), 627634. http://dx.doi.org/10.1016/j.giq.2017.09.005

Khanzode, C. A., Sadore, R. D. (2016). Evolution of The World Wide Web: From Web 1.0 to 6.0. International Journal of Digital Library Services, 6(2), 1-11. www.ijodls.in/uploads/3/6/0/3/3603729/ijodls121.pdf

Karkin, N., Koseoğlu, O., Sobacı, M. Z. (2015). Social Media Policy in Turkish Municipalities: Disparity Between Awareness and Implementation. Surya Nepal, Cécile Paris, Dimitrios Georgakopoulos (Ed.), Social Media for Government Services içinde (s.97-113), e-book, doi: 10.1007/978-3-319-27237-5

Kavanaugh, A., Yang, S., Shoemaker, D., Fox, E.A., Li, L.T., Natsev, P., Sheetz, S., Whalen, T., Xie L. (2012). Social Media Use by Government: From the Routine to the Critical, Government Information Quarterly, 29(4), 480-491. doi:10.1016/j.giq.2012.06.002

Kietzmann, J. H., Hermkens, K., Mccarty, I. P., Silvestere, B. S. (2011). Social media? Get serious! Understanding the functional building blocks of social media, Business Horizons, 54, 241-251. https://doi.org/10.1016/j.bushor.2011.01.005

Layne, K., Lee, J. (2001). Developing fully functional E-government: A four stagemodel. Government Information Quarterly, 18, 122-136. https://doi.org/10.1016/S0740624X(01)00066-1

Magro, M, J. (2012). A Review of Social Media Use in E-Government, Administrative Sciences, 2, 148-161. doi:10.3390/admsci2020148

Mainka, A., Hartmann, S., Stock, W. G., ve Peters, I. (2014). Government and social media: A case study of 31 informational world cities. In 47th Hawaii International Conference on System Sciences (HICSS), 1715-1724. https://arxiv.org/abs/1401.4533

Nepal, S., Paris, C., Georgeakopoulos, D. (2015). An Introduction. Surya Nepal, Cécile Paris, Dimitrios Georgakopoulos (Ed.), Social Media For Government Services içinde, (s. 3-25) e-book, doi: 10.1007/978-3-319-27237-5

Oecd, (2003). The e-government imperative: main findings. March 2003. http://unpan1.un.org/intradoc/groups/public/documents/APCITY/UNPAN015120.pdf, (13.04.2019)

Seigler, D. J. (2017). Social Media Responsiveness in The Public Sector: A Study of Social Media Adaptions in Three Functional Areas of Local Government, International Journal of Organization Theory and Behavior, 20(1), 72-99. https://doi.org/10.1108/IJOTB-20-012017-B003

Tursunbayeva, A., Franco, M., Pagliari C. (2017). Use of Social Media for e-Government in the Public Health Sector: Asystematic Review of Published Studies. Government Information Quarterly, 34, 270-282. https://doi.org/10.1016/j.giq.2017.04.001 